\title{
Paenibacillus forsythiae sp. nov., a nitrogen-fixing species isolated from rhizosphere soil of Forsythia mira
}

Yu-Chao $\mathrm{Ma}^{1,2}$ and San-Feng Chen ${ }^{1,3}$

Correspondence

San-Feng Chen

chensf@cau.edu.cn

\author{
${ }^{1}$ National Key Laboratory for Agrobiotechnology, China Agricultural University, Beijing 100094, \\ PR China \\ ${ }^{2}$ Key Laboratory of Agro-Microbial and Application, China Agricultural University, Beijing 100094, \\ PR China \\ ${ }^{3}$ College of Biological Sciences, China Agricultural University, Beijing 100094, PR China
}

A nitrogen-fixing bacterium, designated strain $\mathrm{T}^{2} 8^{\top}$, was isolated from rhizosphere soil of Forsythia mira. Phylogenetic analysis based on a fragment of the nifH gene and the full-length 16S rRNA gene sequence revealed that strain $\mathrm{T}^{\mathrm{T}}{ }^{\top}$ was a member of the genus Paenibacillus. High levels of 16S rRNA gene similarity were found between strain $\mathrm{T98}^{\top}$ and Paenibacillus durus ATCC $35681^{\top}(97.0 \%)$, Paenibacillus sabinae DSM $17841^{\top}(98.3 \%)$ and Paenibacillus zanthoxyli DSM $18202^{\top}$ (96.8\%). Levels of $16 \mathrm{~S}$ rRNA gene sequence similarity between strain $\mathrm{T}^{\mathrm{T}}{ }^{\mathrm{T}}$ and the type strains of other recognized members of the genus Paenibacillus were below 97.0\%. Levels of DNA-DNA relatedness between strain T98 ${ }^{\top}$ and $P$. durus ATCC $35681^{\top}$, $P$. sabinae DSM $17841^{\top}$ and $P$. zanthoxyli DSM $18202^{\top}$ were $27.6,30.0$ and $32.1 \%$, respectively. The DNA G $+\mathrm{C}$ content of strain $\mathrm{T}^{\mathrm{T}} 8^{\mathrm{T}}$ was $50.4 \mathrm{~mol} \%$. The major fatty acids were anteiso- $C_{15: 0}, C_{16: 0}$ and iso- $C_{16: 0}$. On the basis of its phenotypic characteristics and levels of DNA-DNA hybridization, strain $\mathrm{T}^{\top} 8^{\top}$ is considered to represent a novel species of the genus Paenibacillus, for which the name Paenibacillus forsythiae sp. nov. is proposed. The type strain is T98 $^{\top}\left(=\right.$ CCBAU $10203^{\top}=$ DSM $17842^{\top}$ ).
The genus Paenibacillus was erected by Ash et al. (1993) on the basis of analysis of the 16S rRNA gene sequences of group 3 bacilli. Members of the genus are widely distributed in nature and have physiologically diverse characteristics. Some species consistently show a great capacity to fix atmospheric nitrogen in vitro (Berge et al., 2002; Ma et al., 2007a, b; Ding et al., 2005; Elo et al., 2001; Grau \& Wilson, 1962; Rodríguez-Díaz et al., 2005; Seldin et al., 1984). Here we show that a bacterial strain, designated $\mathrm{T} 98^{\mathrm{T}}$, isolated from rhizosphere soil of Forsythia mira represents a novel nitrogen-fixing species of the genus Paenibacillus.

Strain $\mathrm{T} 98^{\mathrm{T}}$ was isolated from rhizosphere soil of $F$. mira by screening on nitrogen-free medium (Ma et al., 2007a). The nitrogen-free medium contained $20 \mathrm{~g}$ sucrose, $0.1 \mathrm{~g}$ $\mathrm{K}_{2} \mathrm{HPO}_{4}, 0.4 \mathrm{~g} \mathrm{KH}_{2} \mathrm{PO}_{4}, 0.2 \mathrm{~g} \mathrm{MgSO}_{4} .7 \mathrm{H}_{2} \mathrm{O}, 0.1 \mathrm{~g} \mathrm{NaCl}$,

The GenBank/EMBL/DDBJ accession numbers for the partial nifH gene sequence and $16 \mathrm{~S}$ rRNA gene sequence of strain $\mathrm{T}^{\top} 8^{\top}$ are respectively DQ349124 and DQ338443.

A neighbour-joining tree based on $16 \mathrm{~S}$ rRNA gene sequences showing the phylogenetic position of strain $\mathrm{T}^{\mathrm{T}} \mathrm{8}^{\mathrm{T}}$ compared with all recognized species of the genus Paenibacillus is available as supplementary material with the online version of this paper.
$0.01 \mathrm{~g} \mathrm{FeCl}_{3}$ and $0.002 \mathrm{~g} \mathrm{Na}_{2} \mathrm{MoO}_{4}$ per litre of water. One gram of soil was placed in $9 \mathrm{ml}$ sterile water and stirred for $50 \mathrm{~min}$. Aqueous volumes ( $100 \mu \mathrm{l}$ of the mixture) were heated at $80{ }^{\circ} \mathrm{C}$ for $10 \mathrm{~min}$ and then spread on nitrogenfree medium in triplicate and incubated at $30{ }^{\circ} \mathrm{C}$. After 3 days incubation, strain $\mathrm{T}^{\mathrm{T}} 8^{\mathrm{T}}$ was selected for further study.

To confirm the nitrogen-fixing capacity of strain $\mathrm{T} 98^{\mathrm{T}}$, an assay for nitrogenase activity and PCR amplification of the nifH gene were carried out. For measurement of nitrogenase activity, strain $\mathrm{T} 98^{\mathrm{T}}$ and several reference strains were grown on solid RCV mineral medium containing $0.5 \%$ glucose, malate, starch and mannitol (Weaver et al., 1975). After $48 \mathrm{~h}$ at $30{ }^{\circ} \mathrm{C}$, strains were incubated under $2 \%(\mathrm{v} / \mathrm{v})$ acetylene in air for $2 \mathrm{~h}$ and then analysed for ethylene production by GC (Berge et al., 2002). As shown in Table 1, strain $\mathrm{T}^{\mathrm{T}}{ }^{\mathrm{T}}$ exhibited high nitrogenase activity. Whole-cell DNA for PCR amplification was extracted according to standard methods (Sambrook et al., 1989). A 324-bp fragment of the nifH gene was amplified by using two degenerate primers for the nitrogenase Fe protein gene and then sequenced as described by Ding et al. (2005). A phylogenetic tree was generated by the neighbour-joining method by using the software package TREECON for 
Table 1. Nitrogenase activity of strain $\mathrm{T}^{\top}{ }^{\top}$ compared with some nitrogen-fixing species of the genus Paenibacillus

Results are means \pm SD of three determinations.

\begin{tabular}{|c|c|}
\hline Strain & 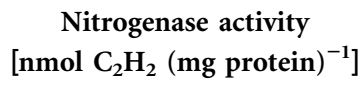 \\
\hline P. durus ATCC $35681^{\mathrm{T}}$ & $2256.8 \pm 46.9$ \\
\hline P. polymyxa ATCC $842^{\mathrm{T}}$ & $3.2 \pm 0.55$ \\
\hline P. macerans ATCC $8244^{\mathrm{T}}$ & $2.48 \pm 0.2$ \\
\hline P. odorifer TOD $45^{\mathrm{T}}$ & $37.62 \pm 18.9$ \\
\hline P. graminis $\mathrm{RSA} 19^{\mathrm{T}}$ & $272.9 \pm 7.9$ \\
\hline P. sabinae DSM $17841^{\mathrm{T}}$ & $3885.9 \pm 72.9$ \\
\hline P. zanthoxyli DSM $18202^{\mathrm{T}}$ & $6282.4 \pm 107.97$ \\
\hline Strain $\mathrm{T} 98^{\mathrm{T}}$ & $1537.0 \pm 10.9$ \\
\hline
\end{tabular}

Windows (Van de Peer \& de Wachter, 1994). Phylogenetic analysis based on $n$ if $H$ gene sequences revealed that strain $\mathrm{T}^{\mathrm{T}}{ }^{\mathrm{T}}$ clustered together with species of the genus Paenibacillus (Fig. 1). Levels of nifH gene sequence similarity between strain $\mathrm{T}^{\mathrm{T}}{ }^{\mathrm{T}}$ and Paenibacillus zanthoxyli DSM $18202^{\mathrm{T}}$, Paenibacillus sabinae DSM $17841^{\mathrm{T}}$, Paenibacillus durus ATCC $35681^{\mathrm{T}}$, Paenibacillus polymyxa DSM $36^{\mathrm{T}}$, Paenibacillus odorifer TOD45 ${ }^{\mathrm{T}}$, Paenibacillus graminis RSA19 ${ }^{\mathrm{T}}$, Paenibacillus macerans ATCC $8244^{\mathrm{T}}$ and Paenibacillus wynnii LMG $22176^{\mathrm{T}}$ were $98.15,97.0,96.30$, $89.0,88.07,80.73,81.65$ and $84.0 \%$, respectively.

A full-length sequence of the $16 \mathrm{~S}$ rRNA gene (1500 bp) was obtained from a PCR product amplified from strain $\mathrm{T} 98^{\mathrm{T}}$ by using the universal forward primer P1 and the universal reverse primer P6. Primer P1 (5'-AGAGTTTGATCCTGGTCAGAACGCT- $3^{\prime}$ ) corresponds to positions $8-37$ and primer P6 (5'-TACGGCTACCTTGTTACGACTTCACCCC-3') corresponds to positions 1479-1506 in the Escherichia coli 16S rRNA gene (Yanagi \& Yamasato, 1993). The amplified 16S rRNA gene was sequenced by using an ABI377 automatic sequencer (Applied Biosystems). The $16 \mathrm{~S}$ rRNA gene sequence of strain T98 ${ }^{\mathrm{T}}$ was aligned with sequences of recognized species of the genus Paenibacillus by using the CLUSTAL_X program (Thompson et al., 1997). Phylogenetic analysis revealed

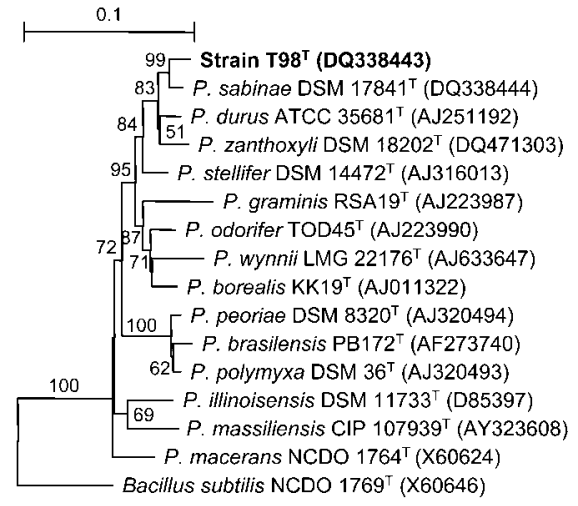

Fig. 2. Neighbour-joining phylogenetic tree based on $16 \mathrm{~S}$ rRNA gene sequences showing the position of strain $\mathrm{T}^{\top}{ }^{\top}$ among species of the genus Paenibacillus. Bacillus subtilis NCDO $1769^{\top}$ was used as an outgroup. Bootstrap analyses were made based on 1000 cycles; only values $>50 \%$ are shown at branch points. Bar, 0.1 substitutions per nucleotide position. An extended version of this tree including all species of Paenibacillus with validly published names is available as Supplementary Fig. S1 in IJSEM Online.

that strain $\mathrm{T} 98^{\mathrm{T}}$ clustered together with Paenibacillus species (Fig. 2; an extended version of this tree is available as Supplementary Fig. S1 in IJSEM Online). Strain T98 ${ }^{\mathrm{T}}$ showed highest $16 \mathrm{~S}$ rRNA gene sequence similarity with $P$. sabinae DSM $17841^{\mathrm{T}}$, P. durus ATCC $35681^{\mathrm{T}}$, P. zanthoxyli DSM $18202^{\mathrm{T}}$ and Paenibacillus stellifer DSM $14472^{\mathrm{T}}(98.3$, 97, 96.8 and $96.5 \%$, respectively). Levels of $16 \mathrm{~S}$ rRNA gene sequence similarity between strain $\mathrm{T}^{\mathrm{T}}{ }^{\mathrm{T}}$ and other recognized members of the genus Paenibacillus were below $96 \%$.

Strain $\mathrm{T} 98^{\mathrm{T}}$ was tested for a range of phenotypic, physiological and biochemical characteristics together with the type strains of closely related Paenibacillus species, including P. durus ATCC $35681^{\mathrm{T}}$, P. sabinae DSM $17841^{\mathrm{T}}$, P. zanthoxyli DSM $18202^{\mathrm{T}}, P$. polymyxa ATCC $842^{\mathrm{T}}, P$. macerans ATCC $8244^{\mathrm{T}}, P$. odorifer TOD $45^{\mathrm{T}}$ and $P$. graminis RSA $19^{\mathrm{T}}$, as reference strains. For observation of cell

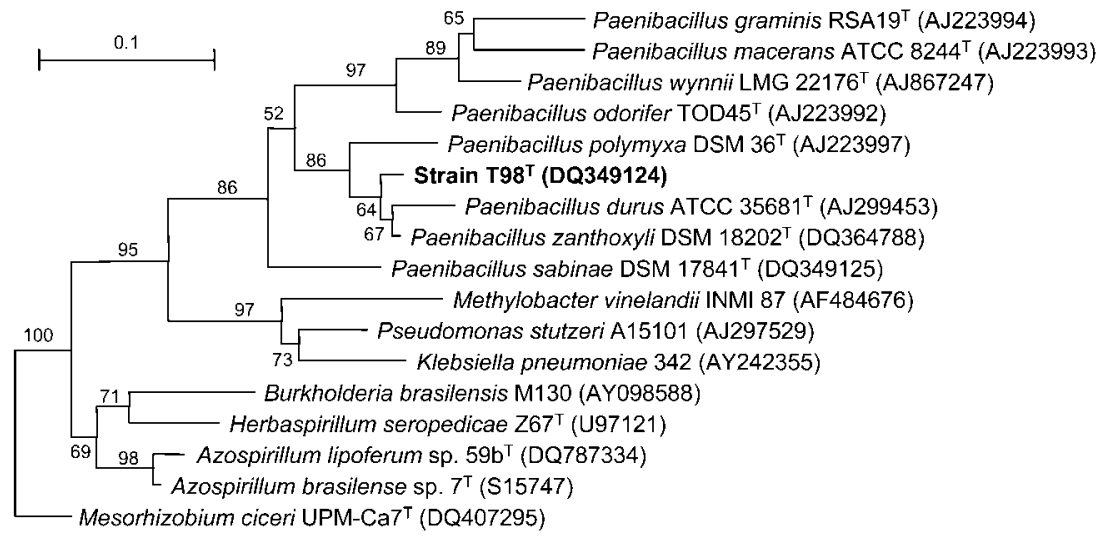

Fig. 1. Phylogenetic tree based on partial nifH gene sequences, showing the position of strain $\mathrm{T}^{\top} 8^{\top}$ in relation to other reference bacterial species. Bootstrap analyses were made based on 1000 cycles; only values $>50 \%$ are shown at branch points. Bar, 0.1 substitutions per nucleotide position. 
morphology, strain $\mathrm{T} 98^{\mathrm{T}}$ was grown on endospore-forming medium $[0.07 \%$ yeast extract, $0.1 \%$ tryptone, $0.1 \%$ glucose, $0.02 \%\left(\mathrm{NH}_{4}\right)_{2} \mathrm{SO}_{4}, 0.02 \% \mathrm{MgSO}_{4} .7 \mathrm{H}_{2} \mathrm{O}$ and $\left.0.1 \% \mathrm{~K}_{2} \mathrm{HPO}_{4}, \mathrm{pH} 7.2\right]$ for $72 \mathrm{~h}$, and cells were then examined by light microscopy. Strain $\mathrm{T}^{\mathrm{T}}{ }^{\mathrm{T}}$ formed ellipsoidal spores, located centrally in swollen sporangia. Colonies on RCV mineral medium agar were circular, convex and glossy with entire margins. Gram-staining demonstrated that cells of strain $\mathrm{T} 98^{\mathrm{T}}$ were Gram-positive or Gram-variable rods $(0.4-0.5 \times 2.0-2.6 \mu \mathrm{m})$. Cell motility was determined by using two methods, i.e. directly by light microscopy and observation of growth spread of cells in test tubes containing semisolid RCV medium after 3 days incubation. Cells of strain $\mathrm{T} 98^{\mathrm{T}}$ were motile. To determine aerotactic ability, bacterial cells were inoculated by mixing them with semisolid medium at $40-50{ }^{\circ} \mathrm{C}$ in test tubes followed by growth at $30{ }^{\circ} \mathrm{C}$ for 3 days. Although cells of strain $\mathrm{T} 98^{\mathrm{T}}$ grew throughout the medium in test tubes, cells near the surface grew better than those near the bottom, suggesting that strain $\mathrm{T} 98^{\mathrm{T}}$ was facultatively aerobic.

Most physiological and biochemical tests, including Gram staining, nitrate reduction, production of dextrin, temperature and $\mathrm{pH}$ optima for growth, activities of catalase, oxidase and the Voges-Proskauer reaction, growth inhibition by $\mathrm{NaCl}$ and lysozyme, were performed according to Gordon et al. (1973), Priest et al. (1981) and Rhodes-Roberts (1981). Hydrolysis of casein, gelatin and starch was determined as described by Cowan \& Steel (1965). Utilization of various substrates as carbon and energy sources was determined as described by Shirling \& Gottlieb (1966). The physiological and biochemical characteristics of strain $\mathrm{T} 98^{\mathrm{T}}$ compared with those of the type strains of closely related Paenibacillus species are presented in Table 2. As shown, strain $\mathrm{T} 98^{\mathrm{T}}$ has physiological properties that allowed its distinction from these recognized Paenibacillus species.

The DNA $\mathrm{G}+\mathrm{C}$ content was determined by using the thermal denaturation protocol (De Ley et al., 1970). The $\mathrm{G}+\mathrm{C}$ content of strain $\mathrm{T} 98^{\mathrm{T}}$ was $50.4 \mathrm{~mol} \%$ (Table 1 ), which is within the range of values for recognized Paenibacillus species (Shida et al., 1997).

For DNA-DNA hybridization experiments, total genomic DNA was extracted and purified according to the method described by Marmur (1961) with some modifications. DNA-DNA hybridization was determined by the initial renaturation rate method (De Ley et al., 1970). Levels of DNA-DNA relatedness between strain $\mathrm{T} 98^{\mathrm{T}}$ and $P$. sabinae DSM $18741^{\mathrm{T}}, P$. durus ATCC $35681^{\mathrm{T}}$ and $P$. zanthoxyli DSM $18202^{\mathrm{T}}$ were $30.0,27.6$ and $32.1 \%$, respectively, indicating that strain $\mathrm{T} 98^{\mathrm{T}}$ represented a species distinct from these three species.

For determination of its cellular fatty acid composition, strain $\mathrm{T} 98^{\mathrm{T}}$ was grown in RVC mineral medium at $30{ }^{\circ} \mathrm{C}$ for 3 days. Analysis was carried out as described by Komagata \& Suzuki (1987) by using the Sherlock Identification System (MIDI) (Sasser et al., 2005). Profiles of the major fatty acids of strain $\mathrm{T} 98^{\mathrm{T}}$ and of closely related Paenibacillus type strains are shown in Table 3. Anteiso- $\mathrm{C}_{15: 0}$, the major fatty acid in recognized members of the genus Paenibacillus, was also the major fatty acid component of strain $\mathrm{T} 98^{\mathrm{T}}(29.87 \%)$.

In summary, phylogenetic analysis based on the full-length $16 \mathrm{~S}$ rRNA gene sequence and on a fragment of the nifH gene sequence, DNA G $+\mathrm{C}$ content, and chemotaxonomic properties revealed that strain $\mathrm{T} 98^{\mathrm{T}}$ was a member of the genus Paenibacillus. Several phenotypic characteristics and levels of DNA-DNA hybridization further demonstrated that strain $\mathrm{T} 98^{\mathrm{T}}$ represents a novel species of the genus Paenibacillus, for which the name Paenibacillus forsythiae sp. nov. is proposed.

\section{Description of Paenibacillus forsythiae sp. nov.}

Paenibacillus forsythiae (for.sy'thi.ae. N.L. gen. n. forsythiae of Forsythia, referring to the plant Forsythia mira, the source of the rhizosphere soil from which the type strain was isolated).

Gram-positive or Gram-variable, facultatively aerobic, motile, straight rods $(0.4-0.5 \times 2.0-2.6 \mu \mathrm{m})$. Ellipsoidal

Table 2. Differential phenotypic characteristics between strain $\mathrm{T}^{\top}{ }^{\top}$ and the type strains of selected Paenibacillus

Strains: 1 , strain T98 $; 2$, P. durus ATCC $35681^{\mathrm{T}} ; 3$, P. sabinae DSM $17841^{\mathrm{T}} ; 4$, P. zanthoxyli DSM $18202^{\mathrm{T}} ; 5, P$. polymyxa ATCC $842^{\mathrm{T}} ; 6, P$. macerans ATCC $8244^{\mathrm{T}} ; 7$, P. odorifer TOD $45^{\mathrm{T}} ; 8$, P. graminis RSA $19^{\mathrm{T}}$. + , Positive; -, negative; ND, not determined. Data for physiological and biochemical characteristics of strain $\mathrm{T} 98^{\mathrm{T}}$ and reference strains are from the present study. Data for $\mathrm{G}+\mathrm{C}$ contents of strain $\mathrm{T} 98^{\mathrm{T}}, P$. sabinae DSM $17841^{\mathrm{T}}$ and P. zanthoxyli DSM $18202^{\mathrm{T}}$ are from the present study. Data for $\mathrm{G}+\mathrm{C}$ contents of $P$. durus ATCC $35681^{\mathrm{T}}, P$. polymyxa ATCC $842^{\mathrm{T}}$, P. macerans ATCC $8244^{\mathrm{T}}$, P. odorifer TOD $45^{\mathrm{T}}$

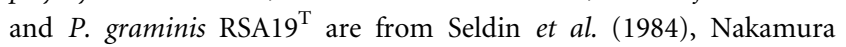
(1987) and Berge et al. (2002).

\begin{tabular}{|lcccccccc|}
\hline Characteristic & $\mathbf{1}$ & $\mathbf{2}$ & $\mathbf{3}$ & $\mathbf{4}$ & $\mathbf{5}$ & $\mathbf{6}$ & $\mathbf{7}$ & $\mathbf{8}$ \\
\hline Growth with lysozyme & - & - & - & - & - & + & + & - \\
$\quad(0.001 \%)$ & & & & & & & & \\
Voges-Proskauer & + & + & + & + & + & + & - & - \\
$\quad$ reaction & & & & & & & & \\
Production of dextrin & - & - & - & - & - & + & - & - \\
Hydrolysis of casein & + & - & - & - & - & - & - & - \\
Acid produced from: & & & & & & & & \\
$\quad$ Sucrose & - & - & - & - & + & + & + & - \\
$\quad$ Glucose & - & + & - & - & + & + & + & + \\
$\quad$ Glycerol & - & - & - & - & + & + & - & - \\
$\quad$ Maltose & - & + & - & - & + & + & + & + \\
Lactose & - & - & - & - & + & + & ND & ND \\
D-Sorbitol & - & - & - & - & + & + & - & - \\
Sodium succinate & + & - & - & - & - & + & - & - \\
$\quad$ L-Aspartate & - & + & - & - & + & + & + & + \\
DNA G+C content & 50.4 & 50.7 & 51.9 & 53.2 & 45 & 53 & 44 & 52.1 \\
$\quad$ mol\%) & & & & & & & & \\
\hline
\end{tabular}


Table 3. Cellular fatty acid profiles of strain $\mathrm{T}^{\mathrm{T}}{ }^{\mathrm{T}}$ and closely related Paenibacillus type strains

Strains: 1, strain T98 $; 2$, P. durus ATCC $35681^{\mathrm{T}}$ (data from Yoon et al., 2003); 3, P. sabinae DSM $17841^{\mathrm{T}}$ (Ma et al., 2007a); 4, P. zanthoxyli DSM $18202^{\mathrm{T}}$ (Ma et al., 2007b); 5, P. stellifer DSM $14472^{\mathrm{T}}$ (Suominen et al., 2003); 6, P. polymyxa DSM $36^{\mathrm{T}}$ (Yoon et al., 2003); 7, P. macerans ATCC $8244^{\mathrm{T}}$ (Elo et al., 2001). Data are percentages of the total fatty acids. NR, Not reported. For unsaturated fatty acids, the position of the double bond can be located by counting from the methyl $(\omega)$ end of the carbon chain; cis isomers are indicated by the suffix $c$.

\begin{tabular}{|c|c|c|c|c|c|c|c|}
\hline Fatty acid & 1 & 2 & 3 & 4 & 5 & 6 & 7 \\
\hline \multicolumn{8}{|c|}{ Saturated straight-chain } \\
\hline$C_{14: 0}$ & 4.85 & 5.0 & 2.96 & 4.87 & 0.7 & 5.0 & 3.7 \\
\hline$C_{15: 0}$ & 1.92 & 2.2 & 1.54 & 2.07 & 0.5 & 3.4 & 0.5 \\
\hline$C_{16: 0}$ & 18.70 & 15.5 & 18.19 & 12.83 & 9.1 & 20.5 & 17.9 \\
\hline $\mathrm{C}_{18: 0}$ & 5.64 & 0.3 & 3.28 & 6.74 & 1.1 & 0.3 & NR \\
\hline \multicolumn{8}{|c|}{ Saturated iso-branched } \\
\hline iso- $\mathrm{C}_{13: 0} 3-\mathrm{OH}$ & 3.74 & $<0.2$ & 1.39 & $<0.2$ & $<0.2$ & NR & NR \\
\hline iso- $\mathrm{C}_{14: 0}$ & 2.64 & 4.7 & 3.20 & 3.99 & 0.6 & 4.7 & 1.8 \\
\hline iso- $\mathrm{C}_{15: 0}$ & 0.97 & 8.7 & 1.37 & 1.51 & 5.5 & 8.7 & 2.6 \\
\hline iso- $\mathrm{C}_{16: 0}$ & 11.48 & 5.3 & 14.40 & 14.85 & 7.7 & NR & 17.1 \\
\hline iso- $\mathrm{C}_{17: 0}$ & 0.98 & 1.1 & 0.79 & 0.61 & 7.0 & NR & 4.1 \\
\hline \multicolumn{8}{|c|}{ Saturated anteiso-branched } \\
\hline anteiso- $\mathrm{C}_{15: 0}$ & 29.87 & 45.4 & 36.59 & 32.19 & 49.9 & 45.5 & 34.5 \\
\hline anteiso- $\mathrm{C}_{17: 0}$ & 4.52 & 2.1 & 6.38 & 3.89 & 16.7 & 2.1 & 16.1 \\
\hline \multicolumn{8}{|l|}{ Unsaturated } \\
\hline $\mathrm{C}_{18: 1} \omega 9 c$ & 4.87 & $<0.2$ & 3.88 & 1.51 & $<0.2$ & $<0.2$ & $<0.2$ \\
\hline
\end{tabular}

spores are located centrally in swollen sporangia. Colonies on RVC mineral medium are circular, convex and glossy with entire margins and measure $2.0-2.5 \mathrm{~mm}$ in diameter after $72 \mathrm{~h}$ at $30{ }^{\circ} \mathrm{C}$. The temperature range for growth is $10-40{ }^{\circ} \mathrm{C}$, with optimum growth at $30{ }^{\circ} \mathrm{C}$. Grows at $\mathrm{pH}$ 4.0-10.0, with optimum growth at $\mathrm{pH} 7.0-7.2$. Grows in the absence of $\mathrm{NaCl}$ and in $3 \%(\mathrm{w} / \mathrm{v}) \mathrm{NaCl}$, but is unable to tolerate $5 \% \mathrm{NaCl}$. Growth is inhibited by $0.001 \%(\mathrm{w} / \mathrm{v})$ lysozyme. Catalase-positive and oxidasenegative. Positive for the Voges-Proskauer reaction. Nitrate is reduced to nitrite. Nitrogen is fixed. Able to utilize succinate to produce acid, but not glucose, sucrose, lactose, fructose, glycerol, xylose, maltose, D-sorbitol, sodium citrate, glycine or L-aspartate. Casein is hydrolysed but gelatin and starch are not. The $\mathrm{G}+\mathrm{C}$ content of the DNA is 50.4 mol\% (thermal denaturation method).

The type strain, $\mathrm{T} 98^{\mathrm{T}}\left(=\mathrm{CCBAU} 10203^{\mathrm{T}}=\mathrm{DSM} 17842^{\mathrm{T}}\right)$, was isolated from rhizosphere soil of the plant Forsythia mira in the Beijing region, China.

\section{Acknowledgements}

We thank Professor Tian-Shen Tao, Chinese Academy of Agricultural Sciences, for technical help. This work was supported by the Chinese National '973' Project (grant no. 001CB108904).

\section{References}

Ash, C., Priest, F. G. \& Collins, M. D. (1993). Molecular identification of rRNA group 3 bacilli (Ash, Farrow, Wallbanks and Collins) using a PCR probe test. Proposal for the creation of a new genus Paenibacillus. Antonie van Leeuwenhoek 64, 253-260.

Berge, O., Guinebretière, M. H., Achouak, W., Normand, P. \& Heulin, T. (2002). Paenibacillus graminis sp. nov. and Paenibacillus odorifer sp. nov., isolated from plant roots, soil and food. Int J Syst Evol Microbiol 52, 607-616.

Cowan, S. T. \& Steel, K. J. (1965). Manual for the Identification of Medical Bacteria. London: Cambridge University Press.

De Ley, J., Cattoir, H. \& Reynaerts, A. (1970). The quantitative measurement of DNA hybridization from renaturation rates. Eur $J$ Biochem 12, 133-142.

Ding, Y., Wang, J., Liu, Y. \& Chen, S. (2005). Isolation and identification of nitrogen-fixing bacilli from plant rhizospheres in Beijing region. J Appl Microbiol 99, 1271-1281.

Elo, S., Suominen, I., Kämpfer, P., Juhanoja, J., Salkinoja-Salonen, M. \& Haahtela, K. (2001). Paenibacillus borealis sp. nov., a nitrogen-fixing species isolated from spruce forest humus in Finland. Int J Syst Evol Microbiol 51, 535-545.

Gordon, R. E., Haynes, W. C. \& Pang, C. H.-N. (1973). The Genus Bacillus. US Department of Agriculture Handbook no. 427. Washington, DC: Agricultural Research Service.

Grau, F. H. \& Wilson, P. W. (1962). Physiology of nitrogen fixation by Bacillus polymyxa. J Bacteriol 83, 490-496.

Komagata, K. \& Suzuki, K. (1987). Lipid and cell-wall analysis in bacterial systematics. Methods Microbiol 19, 161-207.

Ma, Y., Xia, Z., Liu, X. \& Chen, S. (2007a). Paenibacillus sabinae sp. nov., a nitrogen-fixing species isolated from the rhizosphere soils of shrubs. Int J Syst Evol Microbiol 57, 6-11.

Ma, Y., Zhang, J. \& Chen, S. (2007b). Paenibacillus zanthoxyli sp. nov., a novel nitrogen-fixing species isolated from the rhizosphere of Zanthoxyli simulans. Int J Syst Evol Microbiol 57, 873-877.

Marmur, J. (1961). A procedure for the isolation of deoxyribonucleic acid from microorganisms. J Mol Biol 3, 208-218.

Nakamura, L. K. (1987). Bacillus polymyxa (Prazmowski) Mace 1889 deoxyribonucleic acid relatedness and base composition. Int J Syst Bacteriol 37, 391-397.

Priest, F. G., Goodfellow, M. \& Todd, C. (1981). The genus Bacillus: a numerical analysis. In The Aerobic Endospore-Forming Bacteria. Classification and Identification, pp. 91-103. Edited by R. C. W. Berkeley \& M. Goodfellow. London: Academic Press.

Rhodes-Roberts, M. (1981). The taxonomy of some nitrogen-fixing Bacillus species with special reference to nitrogen fixation. In The Aerobic Endospore-Forming Bacteria. Classification and Identification, pp. 315-335. Edited by R. C. W. Berkeley \& M. Goodfellow. London: Academic Press.

Rodríguez-Díaz, M., Lebbe, L., Rodelas, B., Heyrman, J., De Vos, P. \& Logan, N. A. (2005). Paenibacillus wynnii sp. nov., a novel species harbouring the nifH gene, isolated from Alexander Island, Antarctica. Int J Syst Evol Microbiol 55, 2093-2099.

Sambrook, J., Fritsch, E. F. \& Maniatis, T. (1989). Molecular Cloning: a Laboratory Manual, 2nd edn. Cold Spring Harbor, NY: Cold Spring Harbor Laboratory Press.

Sasser, M., Kunitsky, C., Jackoway, G., Ezzell, J. W., Teska, J. D., Harper, B., Parker, S., Barden, D., Blair, H. \& other authors (2005). Identification of Bacillus anthracis from culture using gas chromatographic analysis of fatty acid methyl esters. J AOAC Int 88, $178-181$. 
Seldin, L., van Elsas, J. D. \& Penido, E. G. C. (1984). Bacillus azotofixans sp. nov., a nitrogen-fixing species from Brazilian soils and grass roots. Int J Syst Bacteriol 34, 451-456.

Shida, O., Takagi, H., Kadowaki, K., Nakamura, L. K. \& Komagata, K. (1997). Transfer of Bacillus alginolyticus, Bacillus chondroitinus, Bacillus curdlanolyticus, Bacillus glucanolyticus, Bacillus kobensis, and Bacillus thiaminolyticus to the genus Paenibacillus and emended description of the genus Paenibacillus. Int J Syst Bacteriol 47, 289-298.

Shirling, E. B. \& Gottlieb, D. (1966). Methods for characterization of Streptomyces species. Int J Syst Bacteriol 16, 313-340.

Suominen, I., Spröer, C., Kämpfer, P., Rainey, F. A., Lounatmaa, K. \& Salkinoja-Salonen, M. (2003). Paenibacillus stellifer sp. nov., a cyclodextrin-producing species isolated from paperboard. Int J Syst Evol Microbiol 53, 1369-1374.

Thompson, J. D., Gibson, T. J., Plewniak, F., Jeanmougin, F. \& Higgins, D. G. (1997). The CLUSTAL_X windows interface: flexible strategies for multiple sequence alignment aided by quality analysis tools. Nucleic Acids Res 25, 4876-4882.

Van de Peer, Y. \& de Wachter, R. (1994). TREECON for Windows: a software package for construction and drawing of evolutionary trees for the Microsoft Windows environment. Comput Appl Biosci 10, 569-570.

Weaver, P. F., Wall, J. D. \& Gest, H. (1975). Characterization of Rhodopseudomonas capsulata. Arch Microbiol 105, 207-216.

Yanagi, M. \& Yamasato, K. (1993). Phylogenetic analysis of the family Rhizobiaceae and related bacteria by sequencing of $16 \mathrm{~S}$ rRNA gene using PCR and DNA sequencer. FEMS Microbiol Lett 107, $115-120$.

Yoon, J. H., Oh, H. M., Yoon, B. D., Kang, K. H. \& Park, Y. H. (2003). Paenibacillus kribbensis sp. nov. and Paenibacillus terrae sp. nov., bioflocculants for efficient harvesting of algal cells. Int J Syst Evol Microbiol 53, 295-301. 